\title{
INVESTIGATING IN WHAT WAYS TELEVISION CONSUMPTION INFLUENCES PRESCHOOL AGED CHILDREN AND THEIR DEVELOPMENT
}

The media has repeatedly been connected to hindering the development of children. Particularly, an increase in aggressive behaviour and a decrease in creativity can be linked to children whose television consumption is above average (Valkenburg, 2001). Furthermore, the media is also said to increase the desire for consumption amongst children. Thus, the paper focuses on the way the regular viewing of television and advertisements, affect preschool children as consumers. This is achieved by comparing the drawings of several preschool children who all view the television for different time intervals. The first part of the study examines the television viewing habits of the children. While the second section of the study analyses the relationship between television consumption and the development of the children. The study was conducted with preschool children aged from 4 to 6 years in Hungary. The author discusses the outcomes of the discussions as well as the quality of the children's drawings and reflects on possible effects deriving from the television consumption of the children. To validate results, a children's phycologist also reviewed the drawings.

Keywords: preschool children, qualitative study, drawing analysis, television consumption.

A ccording to research the children in our society today are often aggressive, antisocial and sexually precocious. Simultaneously all these developmental factors are closely linked to the media, accusing it to trigger indiscipline and aggressive behaviour amongst children, as well as premature sexuality (Wilson, 2008).

There has been a long-standing debate as to whether advertising targeted at children should be permitted or not. There is some kind of confusion that surrounds the issue of children and advertising, since the fact that children can distinguish advertising does not necessarily mean that they also understand its persuasive role (Andronikidis Lambrianidou, 2010). Even though in many countries advertising ethics require that advertisements should not be directed at children because they tend to absorb information without filtering it, research results demonstrate that advertisements can affect children, whether they are the advertisers' target or not (Chan, 2000; Oates et al., 2003; Young - De Bruin - Eagle, 2003).

Furthermore, media is said to loosen healthy social bonds. The media turns children into greedy consumers, who only desire things that they do not have the slightest need for. At the same time, the electronic media plays an increasingly important role in our everyday lives. Media consumption today, is a part of numerous regular family rituals, thus entering into the symbolic space of the family receives their own meaning and builds loyalty towards brands (Mitev - Neulinger, 2016). We cannot exclude the children from this specific medium. Since the television is a visual medium, the interpretation does not require any special skills, thus, children can use it of a very young age. Finally, in the age of niche marketing, children have become more valuable, as they significantly influence the purchasing decisions of their parents (Buckingham, 2000). The current paper is a section a larger study dealing with the television consumption of children and the ways their consumer behaviour is altered accordingly.

\section{BACKGROUND}

The ages 4-6 are very important in the development of children. This period is defined as the preschool period and in this period, the foundations of personality are laid, and it is the period in which the child shows the biggest progress in mental, social and artistic areas. Thus, a conscious education process starting with the family and continuing at school is necessary (Yazar - Arifoglu, 2012). The term Generation Alpha was created by McCrindle, which defines the preschool generation regarding their media usage. According to him, anyone born after 2010 falls into this category. Unlike previous generations, which have simply used technology, what makes the Alpha Generation unique, is that they will spend the majority of their everyday lives submerged with technology (McCrindle - Wolfinger, 2009). Another term used to describe this generation was derived by Prensky (2001), who referred to them as "Digital Natives". As these children are all "native speakers" of the digital language of computers and the internet. The knowledge and skills of the Alpha Generation regarding information technologies are different to those from earlier generations (Tootell - Freeman - Freeman, 2014), due to this, it is even more important to analyze this generation's development and behavior thoroughly.

\section{Television consumption impact}

The first studies regarding the television usage of preschool children can be traced back to the 70's. The study of Lyle and Hoffman (1971) examined 157 preschool children and their parents, interestingly 87 percent of the mothers said their preschool-age children asked for food items they saw on television; 91 percent said their children asked for toys they saw on television (Lyle - Hoffman, 1971). In another study, Ward found kindergarten children exhibited confusion and judged the relationship between commercials and reality based on coincidental reasoning or affect 
(Ward - Wackman - Wartella, 1977). While Stephens, Stutts, and Burdick found age was significantly associated with the ability to distinguish between programming and commercials. Only 17 percent of the 5 year olds in the segment with no commercials viewed, correctly identified the non-animated programming (Stephens, 1982).

A more recent Hungarian study by Antalóczy, Pörczi and Vaskuti (2012) on preschool children's media consumption habits confirmed previous findings that nearly one hundred percent of the participants own a media device: only three families owned no mass communication tool. In contrast, approximately one in four preschool children own some form of device, typically a television. The study also revealed that all young people watch television, about 80 percent of them turn on the television every day. The children's typical media consumption pattern is that they typically watch television on their own or with their siblings. Parental control is becoming increasingly diffuse. Finally, the children drew a drawing, which symbolizes what they do in their free time. From the 42 drawings completed, the television, computer or video games only appeared in four cases as the popular leisure activity. In contrast, typically the children drew: swimming, playing with a ball, riding, driving or playing board games. It is important to note that none of the four TV or computer related drawings contained violence or aggression (Antalóczy, 2012). While a study by Hofmeister-Tóth and Malota (2000) showed that the increasing demand created by advertisings, causes 1.5 percent of the daily, and 5-6 percent of the weekly problems of Hungarian families (Hofmeister-Tóth - Malota, 2000).

Also linked to the topic how children's consumer behaviour changes when expressed to the media is a study of Pine and Nash (2002), who interviewed children aged 3-6 years, who had written letters to Father Christmas, regarding the extent and nature of their television viewing. Overall, children who watched more commercial television were found to request a greater number of items from Father Christmas, these children also requested more branded items. A positive correlation was found between watching television alone and the number of requests (Pine - Nash, 2002). Thus, all these recent studies suggest, that not only is the media consumption of preschool children growing drastically, it also affects them as consumers.

Children between 2 and 5 years have the ability to imitate the incidents and behaviors they see. Considering cartoons have scenes changing with fast effects, the importance of cartoons in the lives of children can be witnessed who imitate these. Another characteristic of the children of this age group is being interested in what they see rather than its meaning. Seeing, tasting and hearing develop spontaneously. This role becomes much more important in children between the ages of 3-6, as researches show that the children of this age group are in search of meaning while watching television (Yazar - Arifoglu, 2012).

Valkenburg (2001) discusses all reductive as well as stimulating theories about the link between television consumption with creativity. According to the paper substan- tially more theories underline, that an excessive television consumption leads to a reduction of creativity as well as imaginative play. It also underlines, that so far there are five main areas within this field; the displacement hypothesis, passitivity hypothesis, rapid-pacing hypothesis, visualization hypothesis and arousal hypothesis (Valkenburg, 2001). The hypothesis states, that if images are already created for viewers, as with almost any type of audiovisual media, children only need to view them and fail to create their own, as it would be the case with a book that is only read to the children. While the passitivity hypothesis states, that processing audiovisual material requires little mental effort, thus children become mentally less active (Calvert - Valkenburg, 2013). An important positive exception however, are educational aids and television contents that are designed to teach creativity (Yazar - Arifoglu, 2012), as well as creating content such as characters in video games, however the latter is not applicable to this age group (Calvert - Valkenbury, 2013).

Studies have shown that children in the preschool age can often use the remote control of the television and are often left unsupervised when viewing this medium (Antalóczy, 2012). Now another form of media can be found on the internet, in watching cartoons online on YouTube but also playing various games online. Those under the age of 4 are more likely to spend their time watching video clips. When they reach 4 they also become interested in playing games online (Childwise, 2012; Teuwen et al., 2012). However regarding the internet consumption of preschool aged children, as they are unable to read and write at this age, children who regularly consume various internet channels still rely on their parents in picking the desired channel. Research about the children's internet consumption and the influence of online advertisements is scarce. Holloway, Green and Livingstone (2013) reviewed over 1200 studies regarding children's online access, internet use and behaviours. They found that research focuses on older children and teens. Only $4 \%$ of studies included the $0-4$ age group, while the 5-8 year old group were not studied as a separate group but rather included with older children (Holloway - Green - Livingstone, 2013). Parents are viewed as having a responsibility to deter children from invasive marketing, yet with the rise of non-traditional marketing, it is unclear whether they have the knowledge and skills necessary to undertake this role. In a 2014 study, Spiteri Cornish found that parents recognize online persuasive techniques only when they themselves have been exposed to them (Cornish, 2014). However, most theory so far mainly focused on results from various interviews with children. Thus analysing the drawings of children with high media consumption could therefore be an alternative, as research on children's drawing is becoming more popular. This is mainly because it is a source of understanding a child's cognitive, emotional, visual and motor processes (Frisch, 2006).

\section{Analysing pre-school children's drawings}

Children's drawings have been analysed in the past with several techniques. Researches confirm that children de- 
velop depending on specific age groups; this is also true for their drawing skills. The most widely accepted approach to this is Löwenfeld's sequence (Yazar - Arifoglu, 2012). This sequence includes six different age groups and groups them into different visual developmental stages parallel with the child's personality and identity characteristics (Löwenfeld, 1957). Together with Brittain, Löwenfeld analysed thousands of children's drawings to see if they included features that can be used to describe the drawing development of children (Löwenfeld - Brittain, 1979). Apart from Löwenfeld, Kellog is also one of the scientists who evaluated children's drawings and commented on their development levels. Her work specialized on doodles of toddlers (Kellog, 1969). While Elliot W. Eisner (1967) categorized children's drawing according to their spatial order in fourteen categories. Hopperstad (2008) discusses the quality of the children's play from a semiotic point of view in which children draw signs. These signs consist, at the level of the signifier, of visual-graphic marks such as lines, points, figures and colours. Kress and Van Leeuwen's (1996) theory builds on visual 'grammar'. The study draws attention to the ways that visual features in drawings made by the children in their first year in school can be found to carry ideational, interpersonal and textual meaning (Kress - Van Leuven, 1996). While Coates (2002) examines the drawings collected together with transcriptions of the children's descriptions of their drawings (Coates, 2002). Thibault (1997) argues that children's competence and experience with drawing must also be taken into consideration. It may be the case that children use talk, sounds and gestures because at that time, they did not have access to visual ways of representing their interest in action (Hopperstad, 2008). Any drawing is the result of its maker's active and creative response towards their experiences (Frisch, 2006).

The following study will use the methodology of Kondács - Podmaniczky's (1993) to analyse the drawings of the children. Kondács - Podmaniczky's analysis was taken as a basis for this study as her work takes into consideration the most important and ground-breaking theories of this field such as Löwenfeld and Kellog's drawing development theories, at the same time her work efficiently explains how to analyse children's drawings and what to look out for within specific age groups. Furthermore, Alland (1983) suggests that children in different cultures differ in their details of drawing style, but may also differ in the basic strategies used to construct their drawing. As the sample in this study only incorporates Hungarian children, selecting a paper that analyses the drawings of Hungarian children gives the current paper more consistency.

Considering the statements above, the following paper focuses on the way the media, in specific the regular viewing of television and advertisements, affect the behaviour and development of preschool children, which ultimately impacts them as consumers. It does so, by comparing the drawings of several preschool children who all view the television for different time intervals.

\section{Method}

In the present study, in order to receive an in-depth understanding about the way the media affects preschool children, data was collected from 20 preschool children in $\mathrm{Bu}-$ dapest, in various preschools and then analysed through qualitative research techniques. The participants of the study were 4-6-year-old preschool children, of which 12 were boys and 8 were girls. The families' backgrounds differed in socio-economic status, but were not further analysed. The parents of the children in the study gave their consent of their children participating in the study, and that all materials gained including the drawings can be used and published. (Table 1.)

Firstly, a short interview was conducted with the children. The length of the interview is vital, as children with such a young age have very short concentration ability. In addition, several factors must also be taken into account, which are related to the age of the children.

Table 1.

Characteristics of the study participants $(n=20)$

\begin{tabular}{r|lc} 
Gender & $n$ & $\%$ \\
Female & 8 & 40 \\
Male & 12 & 60 \\
Age & & \\
4 & 9 & 45 \\
5 & 9 & 45 \\
6 & 2 & 10 \\
Private Preschool & 3 & \\
Public Preschool & 17 & 85 \\
& & Source: own construction
\end{tabular}

At preschool level, children do not know the time, thus it is needless to ask them how much time they spend watching television. Instead, one can ask them whether they watch television before or after kindergarten. It is vital to keep the children in their habitual, comfortable surroundings, thus the children were not recorded with cameras. In addition, instead of taking them to a separate room, they were interviewed within their classrooms, but separated from the group as in this age group the children highly influence each other. In order for them to focus on the questions asked. Having an unknown interviewer can also cause discomfort at this age, thus the interviewer spent a few days with the children in their various preschools, prior to the interviews, and making sure the children do not feel they are talking to a stranger. Otherwise, the pre-school teacher would have had to conduct the interview. Another factor that has to be taken into account is that children in this age group have different moods day by day, sometimes they refuse to answer certain questions, and thus sometimes the contents of the questions have to be changed slightly. The first few questions dealt with the television viewing habits of the children, followed by questions of their shopping habits. This section aims to verify the results of An- 
talóczy (2012) as well as Ward (1977), testing aspects such as the general television viewing time and the preferred viewing genre.

Following the interview, a non-verbal form of data collection was selected (this is extremely important when working with children). The children were asked to draw, what they see, when they watch television. This section of the paper will partially aim to analyse whether the findings of Lyle and Hoffman (1971) as well as Pine and Nash (2002) can be verified regarding the theory that nearly all children ask for toys they see on television. These findings could be proven, if the children decide to draw known commercials or items they know from various advertisements.

Finally, the results of the children's drawings were verified in the form of an interview with a child psychologist Petronella Németh-Barna, each drawing was separately discussed and analysed regarding developmental status of the children as well as any possible psychological backlog.

\section{Findings}

From the 20 children participating, only one child did not have a television set at home. In contrast, 11 children claimed they watch television every day. There were children in the sample, who were allowed to watch in the morning and in the afternoon as well. The remaining eight children watch television less often, some only at their grandparent's home. Twelve children knew how to handle the remote control. Most of the children claimed to watch the television alone or with siblings. Only two children from the sample watched television regularly with their parents. Most of the children were allowed to decide for themselves what they watched on television, though some watched DVDs instead of cable television. Each child watched cartoons, some children said they also watch sports regularly. Some children could specifically name the children's channel they watched at home.

The purchasing habits of children were also extremely interesting. From the 20 children who participated in the study, only two did not accompany their parents to the store. From the remaining 18, only five claimed not to ask for anything at the store from their parents. The rest regularly ask for certain goods. In general, the majority of the children mentioned sweets (9), but some children also mentioned toys (3). One child mentioned: "I go to the store with my mom, but I do not ask for anything, because I know she won't buy it. But if I can, I prefer LEGO, they have it at Spar." It is also interesting to note that in addition to the above two brands, the only further brands mentioned regarding shopping is 'Kinder chocolate'.

The children were also asked what they would like from Santa. Interestingly, very few children mentioned branded toys. Only three branded toys were mentioned by the children: two girls asked for Elsa dolls (from the Disney film "Frozen"), two boys mentioned Star Wars games, and four boys asked for Lego. Finally, twelve children were willing to draw at the end of the interview, what they see while watching television. The result was partly reassuring, as all the children drew their favourite cartoons. None of the children drew toys/ or other advertised products. From the sample five were selected for in-depth analysis.

\section{In-depth analysis of the children's drawings}

Figure 1.

Charlie, 5 years and 2 months. "Angry Birds"

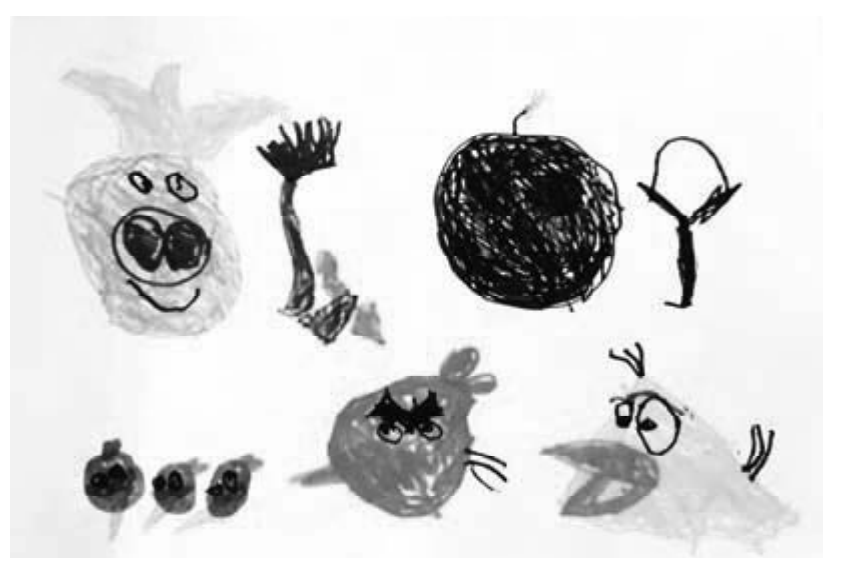

In terms of television consumption, Charlie belonged to those children from the sample that hardly get to watch any television. He was only allowed to watch cartoons at his grandparents' house and not at home. Like all the other children, Charlie drew one of his favourite cartoons the "Angry Birds" (Figure 1.). Compared to the other children, Charlie used the most colours ( 8 different colours), which is very positive. He uses the space of the paper well, while the drawing itself is very developed for a boy his age. The picture shows from left to right, the pig king, a tree, the black angry bird, a sling-shot, 3 small blue angry birds, a red angry bird and a yellow one. Charlie pays attention to detail. All birds have a beak, eyes, even eyebrows. One exception is the black bird, which has not much detail (the eyes and nose look like a skull); this bird is also slightly larger. This is also the only bird, which he actually names "the bomb". This part of his sketch seems much more dynamic, there seems to be a lot more temper and tension radiating (Kondács - Podmaniczky, 1993) from the way he depicted the bomb than the other characters. Other than that, the characters have different facial expressions. The birds look angry, while the pig has a happy face. The pig is also the only one looking at the viewer, while the other birds are all tilted to the left (except for the black one). Unfortunately, this cartoon in itself is a slightly aggressive one, as the pigs constantly try to steal the bird's eggs, who therefore regularly take revenge on them. Whilst the fact that the child is rather focused on "the bomb" character underlines, that the child is rather focused on the aggression aspects of the cartoon.

The interview with Németh-Barna verified this, according to the psychologist one can tell that the boy drew this theme numerously prior to this drawing, this however does not necessarily mean he saw the show often, it can also mean he likes playing the game or that this specific 
cartoon is currently popular within his group of friends. Regarding his age, he can be classified into the creative development stage, since he is closer to the age of 6 and his drawing features resemble this as well. The accentuation of sizes (exaggerations) should be treated with caution (in this case the size of the pig) as its meaning is often unclear. The child might want to emphasize something, or on the other hand, it can display a single experience or trauma (Malchiodi, 2003). Thus, the fact that Charlie uses so many different colours is obviously positive, but it can also mean he is more emotional more mature in terms of expressing his creativity than other boys in his age.

Figure 2.

Daniel, 4 years and 11 months. "Star Wars"

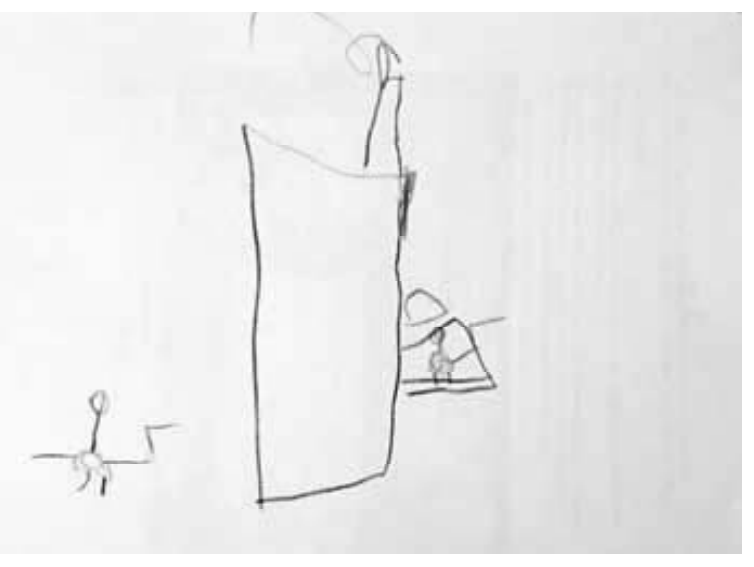

While Daniel (Figure 2.) is the greatest contrast to Charlie, as he has the highest daily television viewing average of all participating children. He watches television before and after kindergarten. He is even allowed to eat in front of the television set. His picture is also a great contrast to the first picture, as he used no other colours except for black. The picture depicts a Jedi with a laser sword. The house in the centre is their ship, while the Jedi in the far right (also with a laser sword) is sitting in a small spaceship. Interestingly, the picture is borderline regarding use of space. As the research in this field still argues what this means exactly, if a child leaves too much blank space on a picture. If done regularly, this can mean inferiority, isolation from the group or anxiety (Kellogg, 1969). A very big contrast to Figure 1., is the lack of detail in Figure 2. Also, if we look at Eisner's 14 Categories of Spatial Treatment in Children's Drawings (Eisner, 1967), Daniel's use of space is only in the first category of 14, as the Jedi is still floating and not standing at the edge of the paper, indicating slight underdevelopment. Finally, comparing Daniel's drawings with those of children in his age in Kondács - Podmaniczky's (1993) works, it becomes even more clear, that there are substantial differences regarding the drawing skills between Daniel and his peers. Children at the age of 5 usually draw a lot more detail on bodies than Daniel did. The face, the hair, hands and feet are completely missing. Most children this age often draw stereotypical houses described by Kellogg (1969) and
Duffy (1998), just like in this picture (although the child verbally highlighted, that this is a "battle ship". Again, the topic if filled with aggressions, as Star Wars itself is a film not intended for preschool aged children. However, interestingly most children adore Star Wars at this age for some reason; most children have not yet seen the actual movie.

According to Németh-Barna, Daniel's sketch is very simple for his age; furthermore, he is slightly uncertain in the use of lines. At the same time, Daniel depicts movement, which is very mature for his age. The figure on the right is standing on a double floor, which can be a sign of security. Interestingly, there is thicker tower-like wall on right side of the spaceship. The phycologist explained that this could be strongly linked with Sigmund Freud's psychosexual stages (Freud, 1954). In brief, this theory applies to the genital stage, also known as the phallic period, which mainly effects children from the age of 3 to 5 , but can extend somewhat further (Goldman, 1982). In Daniel's case, the right side of the picture is affected. Indicating either that the boy currently has a strong relationship with his father (this can be in a positive but also negative sense), however this can also be a symbolism for future aspects and plans (Süle, 1988) (however this also depends on what hand they use, the meaning could reverse if Daniel's dominant hand is the left one). The fact that Daniel failed to draw faces for either of his characters, at the age of 5, if repeated, could be a sign of emotional immatureness.

Figure 3.

László, 5 years and 8 months. "Madagascar"

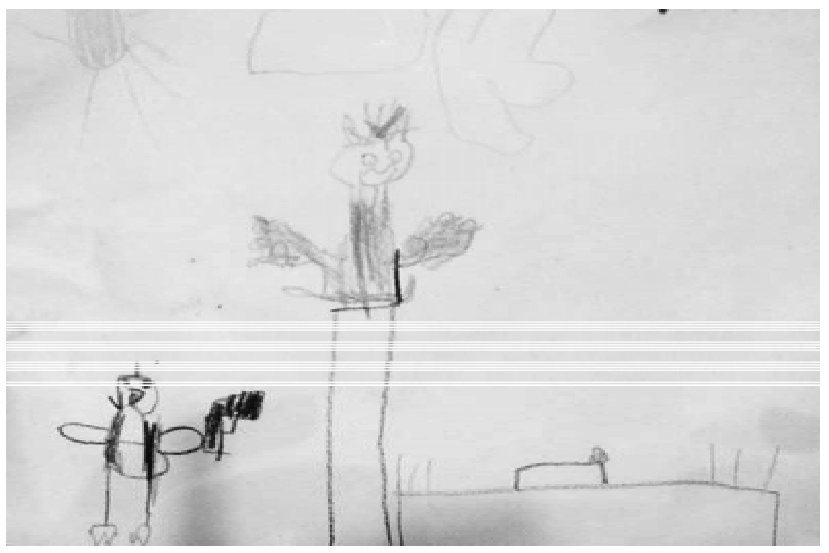

The third drawing above belongs to László (Figure 3.), who is also one of the children in the study whose television consumption is above average. He also chose to draw one of his favourite TV cartoons the Penguins of Madagascar, which stars numerous, once again angry, penguins. Unlike the other two children, László uses colour signals to highlight the importance or salience of a specific element (Kress - Leeuwen, 1996). In this case, the only three things he chose to draw with colour is the sun (yellow), the beak of the penguin (orange) and the legs of the penguin (blue). As László did not explicate what the penguin holds in his hand, we cannot know for sure, but it looks very much like a gun. While the sizes of the penguin and the evil villain 
varies vastly. Some children place certain elements higher up on the page to indicate that some things are in the background, behind other elements, which are drawn further down on the page, causing the effect of them being in the foreground (Kress - Leeuwen, 1996), this could also be the case with the villain. In addition, interestingly, the face of the penguin is very detailed and precisely drawn, while the face of the villain is barely recognizable, according to Kondács - Podmaniczky (1993) the fact the penguin is a lot more detailed, suggests that László has positive feelings towards this character.

In László's case, Németh-Barna once again brought up Freud's phallic period due to the high bar in the centre of the picture, which is also a sign for this specific period. The main hero of the cartoon can also be found here and the hero is much more detailed than anything else in the picture. Presumably, the child identifies with this character, and this may explain the variation in size, as the child's perspective he is small, he looks up to the outside world, which is mostly filled with things much greater than himself. Interestingly, he compensates by drawing the good character much smaller than the villain, however this is normal in children's drawings and can also be found in numerous cartoons and myths (such as David and Goliath). Finally, according to the children's psychologist, the fact that László only used three colours in his drawing is normal at this age the forms are more pronounced and the use of colours if subjective (Malchiodi, 2003).

Krisztina 6 years and 3 months. "My little pony"

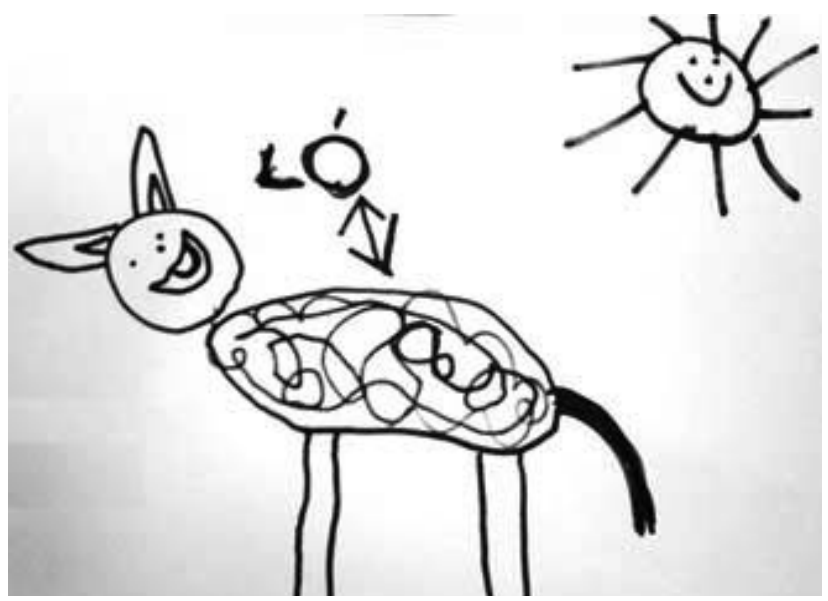

The final two pictures are from two sisters. Their television consumption is slightly above average compared to the sample. As they are allowed to watch TV nearly every day, however, the time they watch television is limited to 1-2 cartoons at a time. The elder sister Krisztina chooses what cartoon the siblings watch. They always watch television together, thus their TV consumption is identical.

Figure 4. depicts Krisztina's picture she wrote 'ló' in Hungarian, which means horse, with an arrow pointing to the horse. As she draws, she highlights that this is not a normal horse; this is a 'my little pony' horse. Krisztina used a black marker for her entire picture. The horse itself is very detailed. Both the horse and the sun are smiling. The overall mood of the picture is a positive one, however she failed to use colour although she had a wide range of colours to pick from, which her little sister clearly made use of. Furthermore, if we look at Eisner's 14 Categories of Spatial Treatment theory (Eisner, 1967), Krisztina is currently in the second category, as no horizon line is drawn, however morphemes (in this case the horse) is standing on bottom edge of paper. This indicates a lag in Krisztina's drawing abilities. The strong doodle on the horse's stomach also needs to be highlighted, as according to Kondács - Podmaniczky's (1993) the child is trying to show some form of emotions.

Figure 5.

Diana 4 years and 2 months. "Elsa is the big one, while Olaf and Anna are in the triangle" (from the Disney movie Frozen).

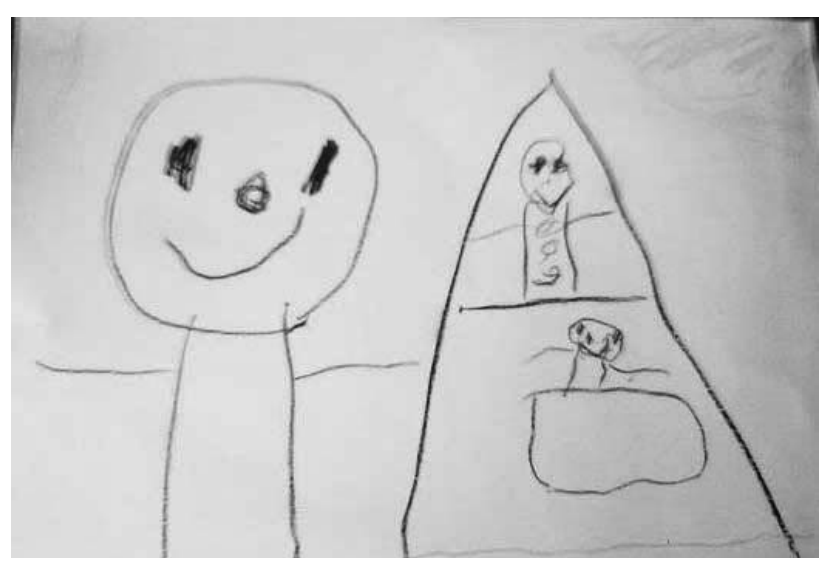

Diana, like all children drew her favourite story, Frozen. The objects and actors are arranged according to size. Visually, the result is very ordered, allowing each element to stand out. She used graphic lines to frame elements, creating a triangle, in which she placed two of the actors (Hopperstad, 2010). Diana only used two colours yellow and blue, however as the title Frozen indicates, there is lots of ice and snow in the movie, thus the selection of colour is justifiable. Figure 5. is also generally a picture which does not show aggressions of any kind. In addition, Diana's drawing abilities are adequate for her age. The way she drew the three characters is what Kondács - Podmaniczky's (1993) refers to as the so-called "head-leg" human figure, which is the initial form of human representation by children.

Whilst analysing the sister's drawings, Németh-Barna concluded that in terms of this one drawing, both sisters have a slight lag for their age in terms of drawing. Especially the older sisters drawing is not detailed enough, in terms of complexity. She especially highlighted the fact that the head of the horse is in a twisted, unnatural position. Although presumably she intended for the horse to look at the sun, which in turn is a sign of mutual interaction and thus may indicate good socialization skills 
and thus reflects a positive mood. The fact that the body is decorated in such as way can mean numerous things. A perspective drawing (appears at the age of 6-7) prequel to the X-ray perspective, when the inside of a living being or object is displayed (Malchiodi, 2003). Subsequently, it can refer to the sensitivity of the abdominal/digestive system, or disease/anxiety. An interview with the parents regarding this could have brought more insight. In addition, the very detailed and thick tail could also mean some kind of accentuation and thus underline Freud's psychosexual theory. Regarding the younger sister, as mentioned, her drawing skills seem also slightly immature, however less than that of her older sister. Diana draws the typical head/ body figure, which is a common form children draw at that age. Diana merged the head and body without evidence of a neck; the head and body are thus one entity. In addition, the drawing reflects a positive mood as well. (Table 2.)

Table 2.

Summary of the expert's interpretations of the drawings

Summary
- Drew this theme numerously
- In the creative development stage
- Accentuation of sizes should be treated
with caution
- Colour use is positive, but can mean he
is emotionally more mature

Source: own construction

\section{DISCUSSION}

Overall the drawings were colourful and cheerful, however not all were free of aggression. The outcomes were able to verify the results of Frisch (2006) as the drawings resulted as an active response towards the children's media experiences. A pattern could be observed between the amount of media consumption and the children's drawing abilities for their various ages. The boy who viewed the least amount of television from the sample had drawing skills that were beyond average for his age, while the boys drawing abilities, who viewed the most television, were rather underdeveloped for his age, taking into consideration Eisner and Kondács - Podmaniczky's findings. A possible explanation for this could be, that the child who spends less time watching television, has more time for other activities, such as developing his or her drawing skills further. The findings are therefore in line with the passitivity hypothesis, which states that processing audiovisual material requires little mental effort, thus children become mentally less active. Especially the visualization hypothesis underlines the finding of the current paper, suggesting that children only view audiovisual media and thus do not create their own (Calvert - Valkenburg, 2013).

A similar pattern evolved regarding the use of colour. The boy who viewed the least amount of television had the most colourful picture, while the two children decided to use black colour only (one child whose television consumption was above average and one, whose consumption was average). At the same time, it has to be noted, that according to the interviewed child psychologist, the use of colour is not necessarily an indicating factor of creativity, especially in pre-school aged children. Between 4-7 years, children are more interested in what kind of shape an object has rather than its colour. The colour selection, if at all, is often subjective, it is difficult to draw conclusions from them. The discovery of the relationship between colours and objects begins between 6-9 years (Malchiodi, 2003). The use of colour can however, be linked to the emotional state of the child. However, it is also necessary to refer to Thibault's (1997) theory that children's competence and experience with drawing must be taken into consideration, as the boy with the vast amount of television consumption, tried to compensate his lack of artistic skills with a greater depth of verbal explanation.

Interestingly, at first glance, the drawings appeared to be free of media influence as none of the children drew actual commercials or advertised products. However, they all decided to draw their favourite cartoon. At this point, it is important to mention, that the toy industry uses these cartoons and movies to sell various merchandise products, which makes up a substantial part of their annual sales.

Finally, if the gender differences are compared amongst the children's drawings, the findings are partially in line with that of Kress (1997) and Hopperstad (2008), as both described boys who demonstrated interest in action and drama whilst drawing. These study's findings also highlight, the only substantial difference between the genders drawings are that all drawings of the boys contained some form of aggression, while on the contrary not only did none of the girl's drawings contain any aggression, their pictures were extremely positive and happy. Thus the findings show why the effects of media violence have been highly debated, whereas Freedman concluded 
that the negative effects of violent media content are questionable, Bushman and Anderson (2001) recall numerous studies that demonstrate a consistent link between violent programming and increased aggression, especially among children (Jones, 2010). The findings of this paper suggest that today's programs aired and targeted specifically for boys are by far more violent than those targeted at girls, at the same time the additional interview indicated a slightly higher extent of conflicts is normal in children that are currently in the phallic stage of their development.

\section{Conclusion}

Overall, the paper contributes to findings in this specific field, as it underlines that an increased television consumption has an impact on the development of children. However at this point, it is important to highlight, that the current results are true for the current, very limited sample. Thus, further research and a greater sample is necessary in order to validate the current results. An increased television consumption seems to influence the drawing abilities and thus the overall development of the children, which could be identified whilst comparing the drawings of the child who viewed television the most, versus the child who view the least amount of television. The usage of space, the details found within the drawings, the explanations of the drawings by the children and the usage of symbolism, all underlined the findings. Especially Eisner's Spatial Treatment in Children's Drawings (Eisner, 1967) highlighted that certain children lagged regarding the use of space in their drawings compared to their age, especially the child with the most television consumption.

Furthermore, gender differences could be witnessed, namely that television consumption, especially in preschool boys, promotes aggressions, which on the long run also can have a serious effect on the child's mental development, however it can be argued to what extent the irritations depicted can be regarded normal considering the developmental stage they are currently in.

Most importantly, none of the children drew actual advertisements or advertised products, however all the children drew their favourite television cartoon. Interestingly however, all these programs depicted sell numerous forms of merchandising products, thus the cartoons that are aired in children channels nowadays, are indirectly extended commercials for their own merchandise products.

\section{Limitations}

Despite the inherent strengths of the present study, some limitations need to be considered. Firstly, although the sample size is large enough for a qualitative study of this manner, a wider range of children (especially those who have hardly any contact with television programs) could have added to the value of the study. Furthermore, past research suggests, that analysing only one picture of a given child is not enough to get a complete picture, as it can often be misleading. A series of pictures would be necessary for an adequate and thorough analysis, especially in analysing the child's development (Kondács - Podmaniczky, 1993). This factor was also highly emphasized by the interviewee Németh-Barna, who underlined that it is not possible to make generalizations based on one analysis. It would be necessary to analyse a larger series of drawings by the same children as well as the gathering of further information from the children's parents in order to make substantial conclusions about their developmental state. Every child is at different stages regarding its brain maturation, socioeconomic status, their willingness to draw, thus further tests would be needed to draw accurate conclusions.

A further limitation of the paper is that the focus of the paper lies on the television consumption of the children, as today, this generation also enjoys consuming various other forms of media such as the internet. Likewise, a wider focus could have been set on the exact narratives of the children whilst drawing. Finally, it has also not been screened whether the children participating in the study have any sorts of social disabilities (for example dysgraphia or autism), which could perhaps distort the results.

\section{Further research}

Many issues raised in the research could have been answered with a detailed questionnaire from the children's parents. For instance, information regarding the overall development of the children would have been a valuable input, or to know what exactly the children watch at home; what channels they prefer or which DVD's they look at (of course DVD's do not contain targeted advertising, which would have been another valuable information). Thus, such a survey could be used to expand the current research further.

Moreover, the children from the study could be analysed over various time periods, repeating the drawing sessions quarterly, in order to track every child's individual developmental process. In addition, the current study could be repeated with an international sample, which could also bring new, interesting insights. Finally, a very interesting aspect of this research could be in what ways creativity is affected by the television consumption of children. In the current limited sample, first minor tendencies could be detected that the creativity of the children did intact suffer under an increased television consumption; however, this still needs to be examined further.

\section{Managerial implications}

The current study has several practical implications. The results suggest, that the media influence affects preschool children in numerous ways, thus it lies in the responsibility of the advertising companies and decision-makers to protect the future generations and to ensure that they develop in an adequate and healthy manner. However, as we live in a profit-oriented economy perhaps the first steps in the right direction could be some form of harsher legislation regarding advertisements directed to children. Furthermore, it is necessary to educate parents (through kindergartens and schools) of the affects excessive media consumption can have on their children, as they are often completely unaware of this specific issue. It is essential that parents learn how to properly guide their children in the inevitable world of media. 


\section{REFERENCES}

Alland, A. (1983): Playing with form: Children draw in six cultures. Columbia University Press.

Andronikidis, A. I. - Lambrianidou, M. (2010): Children's understanding of television advertising: A grounded theory approach. Psychology \& Marketing, 27 (4), 299322. o.

Antalóczy, T. - Pörczi. Zs. - Vaskuti, G. (2012): Óvodások távirányítóval - Média és filmfogyasztás a legifjabb nemzedekek köreben. Kultura és Közösség, 4 (3), 143153. o.

Buckingham, D. (2000): After the Death of Childhood - growing up in the age of electronic media. Polity Press

Bushman, B. J. - Craig, A. A. (2001): Media violence and the American public: Scientific facts versus media misinformation. American Psychologist, 56 (6-7), 477. o.

Calvert, S. L. - Valkenburg, P. M. (2013): 28 The Influence of Television, Video Games, and the Internet on Children's Creativity. In: The Oxford Handbook of the Development of Imagination, 438. o.

Chan, K. (2000): Hong Kong children's understanding of television advertising. Journal of Marketing Communications, 6 (1), 37-52. o.

Childwise (2012): The Monitor Pre-school Report 2012: Key behaviour patterns among 0 to 4 year olds. Norwich

Coates, E. (2002): "I forgot the sky!" Children's stories contained within their drawings. International Journal of Early Years Education, 10 (1), 21-35. o.

Duffy, B. (1998): Supporting Creativity and Imagination in the Early Years. Buckingham: Open University Press

Eisner, E.W. (1967): A comparison of developmental drawing characteristics of culturally advantaged and culturally disadvantaged children. Project No. 3086 (U.S. Dept. of Health, Education, and Welfare, Office of Education, Bureau of Research, September 1967.)

Freedman, J. L. (2003): Media Violence and Its Effect on Aggression: Assessing the Scientific Evidence. Canadian Psychological Association, 44 (2)

Freud, S. - Princess Marie Bonaparte (1954): The origins of psychoanalysis. London: Imago

Frisch, N. S. (2006): Drawing in Preschools: A Didactic Experience. International Journal of Art \& Design Education, 25(1), 74-85. o.

Goldman, R. - Goldman J. (1982): Children's Sexual Thinking: A Comparative Study of Children Aged 5 to 15 Years in Australia, North America, Britain and Sweden. Lawrence: Routledge \& Kegan Paul

Hofmeister-Tóth Ágnes - Malota Erzsébet (2000): Reklámok a gyerek és a szülő szemével. Marketing \& Menedzsment, 34 (2), 33-38. o.

Holloway, D. - Green, L. - Livingstone, S. (2013): Zero to eight: Young children and their internet use. London: London School of Economics

Hopperstad, M. H. (2008): How children make meaning through drawing and play. Visual Communication, Sage, 7(1), 77-96. o.
Hopperstad, M. H. (2010): Studying meaning in children's drawings. Norway Journal of Early Childhood Literacy, 10(4), 430-452. o.

Jones, T. - Cunningham, P. H. - Gallagher, K. (2010): Violence in advertising. Journal of Advertising, 39 (4), 11-36. o.

Kellogg, R. (1955): What Children Scribble and Why. Palo Alto: N.P. Publications

Kellogg, R. (1969): Analyzing Children's Art. Palo Alto: National Books

Kondács Mihályné - Podmaniczky Mária (1993): Vizuális nevelés az óvodában. Budapest: Calibra Publications

Kress, G. R. - Van Leeuwen, T. (1996): Reading Images. The Grammar of Visual Design. London: Routledge

Kress, G. R. - Van Leeuwen, T. (1997): Before Writing. Rethinking the Paths to Literacy. London: Routledge

Lowenfeld, V. (1957): Creative and Mental Growth (3rd edition), New York: The Macmillan Company

Lowenfeld, V. - Brittain, W. L. (1979): Creative and Mental Growth. New York: Macmillan Publishing

Lyle, J. - Hoffman, H. R. (1971): Explorations in Patterns of Television Viewing by Preschool-age Children, Television and Social Behavior. (4) Washington, D.C.: U.S.

Government Printing Office, 253-278. o.

Malchiodi, C. A. (2003): A gyermekrajzok megértése. Budapest: Animula Kiadó

McCrindle, M. - Wolfinger, E. (2009): The ABC of XYZ: Understanding the global generations. Kensington: University of New South Wales Press

Mitev, A. Z. - Neulinger, A. (2016): Sikeres és sikertelen rítustipológia a családi rítusok elemzésén keresztül. Vezetéstudomány, 47 (7), 29-40. o.

Oates, C. - Blades, M. - Barrie, G. - Don, J. (2003): Children's understanding of television advertising: A qualitative approach. Journal of Marketing Communications, 9, 59-71. o.

Pine, K. J. - Nash, A. (2002): Dear Santa: The effects of television advertising on young children. International Journal of Behavioral Development, 26 (6), 529-539. o.

Prensky, M. (2001): Digital natives, digital immigrants. part 1. On the horizon, 9(5), 1-6. o.

Spiteri Cornish, L. (2014): 'Mum, can I play on the internet?' Parents' understanding, perception and responses to online advertising designed for children. International Journal of Advertising, 33(3), 437-473. o.

Stephens, N. - Stutts, M. A. - Burdick R. (1982): Preschoolers' ability to distinguish between television programming and commercials. Journal of Advertising, 11(2), 16-26. o.

Süle, F. (1988): A Fa-rajz teszt. In: Mérei F. - Szakács F. (szerk.): Pszichodiagnosztikai Vademecum. Budapest: Tankönyvkiadó

Teuwen, J. - De Groff, D. - Zaman, B. (2012): Flemish Preschoolers Online: A mixed-method approach to explore online use, preferences and the role of parents and siblings. Leuven: Etmaal van de Communicatiewetenschap 
Thibault, P. J. (1997): Re-reading Saussure: The Dynamics of Signs in Social Life. London: Routledge

Tootell, H. - Freeman, M. - Freeman, A. (2014): Generation alpha at the intersection of technology, play and motivation. In: System Sciences (HICSS), 2014 47th Hawaii International Conference on (82-90 o.). IEEE.

Valkenburg, P. M. (2001): Television and the child's developing imagination. Handbook of Children and the Media, 121-134. o.

Ward, S. - Wackman, D. B. - Wartella, E. (1977): How children learn to buy. The development of consumer information-processing skills. Oxford: Sage, 191-246. o.
Wilson, B. J. (2008): Media and Children's Aggression, Fear, and Altruism, Children and Electronic Media Issue. The Future of Children, 18 (1), 87-118. o.

Yazar, T. - Arifoglu, G. (2012): A research of audio visual educational aids on the creativity levels of 4-14 year old children as a process in primary education. Procedia-Social and Behavioral Sciences, 51, 301-306. o.

Young, B. M. - Bruin, A. - Eagle L. (2003): Attitudes of parents toward advertising to children in the UK, Sweden and New Zealand. Journal of Marketing Management, 19 (3-4), 475-490. o. 